\title{
E-LAW CONSULT SEBAGAI SALAH SATU SOLUSI PERLINDUNGAN HUKUM BAGI GURU-GURU DI JAWA TENGAH ${ }^{1}$
}

\author{
Maryanto $^{1 *}$, Toebagus Galang Windi Pratama ${ }^{2}$, Ika Menarianti ${ }^{3}$ dan Achmad Buchori ${ }^{4}$ \\ ${ }^{1}$ Fakultas Pendidikan Ilmu Pengetahuan Sosial dan Keolahragaan UPGRIS, Semarang \\ ${ }^{2}$ Fakultas Hukum UPGRIS, Semarang \\ ${ }^{3,4}$ Fakultas Pendidikan Matematika, Ilmu Pengetahuan Alam, dan Teknologi Informasi UPGRIS, \\ Semarang \\ maryanto_drs@yahoo.co.id
}

\begin{abstract}
Teacher in Indonesia has had many problems regarding their job as many of them are being tried to the court regarding their professional occupation because unlike other professional occupation that is given law immunity in doing their job. This urges the author to study the weaknesses of current socialization and law protection of teachers' rights as professional educators in Central Java and how E-Law consult application help them in a juridical-empirical study. The results showed that the weaknesses of teacher's law protection are mainly because the lack of understanding of the law and E-Law Consult can be a mean to assist teachers in dealing with legal problems related to their profession as a teacher.
\end{abstract}

Keywords: E-Law Consult; Law Protection; Teacher; Central Java

\begin{abstract}
Abstrak
Guru di Indonesia memiliki banyak kendala terkait pekerjaannya karena banyak di antaranya yang diadili di pengadilan terkait pekerjaan profesionalnya karena tidak seperti pekerjaan profesional lain yang diberikan kekebalan hukum, guru tidak memilikinya di dalam menjalankan tugasnya. Hal ini mendorong penulis untuk mempelajari kelemahan sosialisasi dan perlindungan hukum terhadap hak guru sebagai tenaga pendidik profesional di Jawa Tengah dan bagaimana aplikasi Konsultasi E-Law membantu mereka ke dalam studi yuridis-empiris. Hasil penelitian menunjukkan bahwa kelemahan perlindungan hukum terhadap guru adalah terutama karena kurangnya pemahaman hukum dan Konsultasi E-Law dapat menjadi sarana untuk membantu guru dalam menangani permasalahan hukum terkait profesinya sebagai guru.
\end{abstract}

Kata Kunci: E-Law Consult; Perlindungan Hukum; Guru; Jawa Tengah

\footnotetext{
${ }^{1}$ Artikel hasil Penelitian Dasar Unggulan Perguruan Tinggi RISTEKBRIN Tahun 2020.
} 


\section{A. Pendahuluan}

Peranan, tugas, dan fungsi guru sangat penting dalam melaksanakan sistem pendidikan nasional dan mewujudkan tujuan pendidikan nasional. Kunci utama peranan, tugas dan fungsi guru adalah profesionalitas, kesejahteraan, dan perlindungan hukum bagi guru harus diberikan secara optimal. Kunci itu kini ada di dalam Undang-undang Guru dan Dosen, Undang-undang Sistem Pendidikan Nasional dan berbagai peraturan perundangan yang harus diimplementasikan secara optimal berdasarkan nilai keadilan.

Hal paling tampak terkait dengan belum terimplementasikannya Undang-undang Nomor 14 tahun 2005 tentang Guru dan Dosen ini secara baik adalah upaya perlindungan hukum bagi guru dalam tugastugas profesionalitasnya. Banyak guru yang terlibat dalam kasus pidana berkenaan dengan Undang-undang Nomor 23 Tahun 2002 tentang Perlindungan Anak sebagaimana diubah dengan Undangundang Nomor 35 Tahun 2014, dan juga Kitab Undang-undang Hukum Pidana khususnya di sekolah.

Fakta yang ditemukan di lapangan mendukung hal ini dimana dalam hal ini kenyataan di lapangan sama sekali tidak menunjukkan perlindungan hukum bagi guru sebagaimana mestinya. Berdasarkan data penanganan perkara dari Lembaga Konsultasi Guru dan Bantuan Hukum (LKBH PGRI) Jawa Tengah, dalam kurun waktu tahun 2011 hingga 2018 terdapat cukup banyak kasus pidana, perkara perdata, dan bahkan dalam Kasus Tata Usaha Negara yang berhubungan dengan tugas profesional guru. Tercatat di Jawa Tengah sendiri LKBH PGRI menangani 11 perkara dengan guru sebagai tergugat dan 1 perkara berstatus tersangka bahkan terpidana (S. Budoyo, 2018).

Data yang diperoleh dari Lembaga Konsultasi dan Bantuan Hukum (LKBH PGRI) dipersepsikan oleh penulis sebagai bukti yang cukup tinggi kriminalisasi terhadap guru, bahkan oleh penulis juga secara tidak langsung menunjukkan rendahnya kinerja Persatuan Guru Republik Indonesia (PGRI) sebagai organisasi profesi guru dalam memberikan perlindungan kepada guru.

Permasalahan ini muncul pada dasarnya dikarenakan kecenderungan orang tua siswa atau masyarakat yang mempermasalahkan kinerja guru. Masyarakat memiliki kecenderungan memperkarakan tindakan guru dalam menjalankan profesinya, dalam hal memberikan sanksi fisik, non fisik, memberikan nilai/tidak menaikkan kelas/tidak meluluskan peserta didik, dan lain-lain yang dapat mengantarkan guru ke penjara dan mengancam status kepegawaiannya apabila itu berkaitan dengan hukum pidana. Di sisi lain guru dituntut menghasilkan siswa pintar dan berbudi. Padahal di dalam Undang-undang Nomor 14 Tahun 2005 secara tegas guru mendapatkan perlindungan selama menjalankan tugas profesionalnya sebagaimana dapat dilihat pada Undangundang Nomor 14 Tahun 2005 Guru dan Dosen Pasal 39 yakni sebagai berikut: (1) Pemerintah, pemerintah daerah, masyarakat, organisasi profesi, dan/atau satuan pendidikan wajib memberikan perlindungan terhadap guru dalam pelaksanaan tugas; (2) Perlindungan sebagaimana dimaksud dalam pernyataan di atas meliputi perlindungan hukum, perlindungan profesi, serta perlindungan keselamatan dan kesehatan kerja; (3) Perlindungan hukum mencakup perlindungan hukum terhadap tindak kekerasan, ancaman, perlakuan diskriminatif, intimidasi, atau perlakuan tidak adil dari pihak peserta didik, orang tua peserta didik, masyarakat, birokrasi, atau pihak lain; (4) Perlindungan profesi mencakup perlindungan terhadap pemutusan hubungan kerja yang tidak sesuai dengan peraturan perundang-undangan, pemberian imbalan yang tidak wajar, pembatasan dalam menyampaikan pandangan, pelecehan terhadap profesi, dan pembatasan/pelarangan lain yang dapat menghambat guru dalam melaksanakan tugas; (5) Perlindungan keselamatan dan kesehatan kerja sebagaimana dimaksud 
mencakup perlindungan terhadap risiko gangguan keamanan kerja, kecelakaan kerja, kebakaran pada waktu kerja, bencana alam, kesehatan lingkungan kerja, dan/atau risiko lain.

Kedudukan guru semakin rendah terlebih apabila para guru tidak memahami adanya Undang-undang Nomor 23 Tahun 2002 tentang Perlindungan Anak sebagaimana diubah dengan Undang-undang Nomor 35 Tahun 2014, sementara orang tua siswa atau masyarakat sudah terlebih dahulu memahaminya. Karena itu selain dituntut selalu meningkatkan kemampuan profesionalnya para guru juga harus memiliki pemahaman hukum yang baik, khususnya yang berkaitan dengan perlindungan anak sebagaimana diatur dalam Undang-undang Perlindungan Anak.

Pemahaman terhadap ketentuan Undang-undang Nomor 23 Tahun 2002 tentang Perlindungan Anak sebagaimana diubah dengan Undang-undang Nomor 35 Tahun 2014, Kitab Undang-undang Hukum Pidana dan peraturan perundang-undangan lainnya sangat penting agar proses pendidikan bagi para siswa berjalan optimal dan guru juga terhindar dari permasalahan hukum yang mungkin terjadi. Para guru harus memahami, bahwa tindakan guru seperti mencubit, menjewer, menampar, memukul, menendang, membentak dan hukuman fisik lainya yang pada masa lalu dinilai wajar sebagai upaya untuk mendidik siswa, kini tindakan yang sama dapat dipersoalkan secara hukum atau setidaknya guru dapat dilaporkan ke dewan kehormatan profesi karena dinilai melanggar kode etik guru.

Sebagaimana diatur dalam Pasal 4 Undang-undang Nomor 23 Tahun 2002 tentang Perlindungan Anak sebagaimana diubah dengan Undang-undang Nomor 35 Tahun 2014, setiap anak berhak untuk dapat hidup, tumbuh, berkembang, dan berpartisipasi secara wajar sesuai dengan harkat dan martabat kemanusiaan, serta mendapat perlindungan dari kekerasan dan diskriminasi, sebagaimana tersebut dalam
Pasal 16 ayat (1) Undang-undang Nomor 35 Tahun 2014.

Undang-undang Nomor 23 Tahun 2002 tentang Perlindungan Anak sebagaimana diubah dengan Undang-undang Nomor 35 Tahun 2014 mengatur mengenai kewajiban para pemangku kewajiban dalam upaya perlindungan anak, sebagaimana disebutkan dalam Pasal 54 dimana "setiap anak di dalam dan di lingkungan sekolah wajib dilindungi dari tindakan kekerasan yang dilakukan oleh guru, pengelola sekolah atau teman-temannya di dalam sekolah yang bersangkutan atau lembaga pendidikan lainnya".

Untuk mengatasi masalah itu, Hukum mengenal istilah adagium fiksi hukum, yaitu dimanapun siapapun tanpa kecuali dianggap tahu hukum. Meskipun adagium ini sudah lama ditinggalkan, tetapi faktanya pandangan ini masih dianut dunia peradilan. Putusan Mahkamah Agung (MA) maupun Mahkamah Konstitusi (MK). Putusan MA No. 645K/Sip/1970 dan putusan MK No. 001/PUU-V/2007 masih menunjukkan bahwa keduanya memuat prinsip yang sama: "ketidaktahuan seseorang akan undangundang tidak dapat dijadikan alasan pemaaf'.

Kurangnya pemahaman masyarakat terhadap hukum disebabkan banyak faktor. Tetapi secara umum lebih disebabkan akses mereka terhadap sumber-sumber informasi hukum sangat minim. Misalnya, Lembaran Negara (LN) dan Tambahan Lembaran Negara (TLN), tempat undang-undang beserta penjelasannya dimuat, tidak diproduksi massal dan tidak gratis. Jika saja semua peraturan yang diterbitkan pemerintah bisa diakses dengan mudah, kemungkinan besar masyarakat semakin memahami hukum.

Kurangnya pemahaman masyarakat terhadap hukum dapat diselesaikan dengan cara sosialisasi atau penyuluhan atau juga melalui pendidikan hukum. Masyarakat juga dapat mengakses melalui www.hukumonline.com. Namun tentu hal tersebut tidak dapat menembus hingga lini terdalam dari masyarakat karena untuk 
melakukannya diperlukan tidak hanya materi, namun juga tenaga dan waktu yang tidak sedikit sehingga tidak dapat menjangkau secara maksimal.

Perkembangan teknologi yang semakin pesat, merubah cara pandang masyarakat terhadap teknologi. Teknologi menjadi kebutuhan penunjang dalam mencari informasi. Potensi ini dapat memungkinkan masyarakat mengenal hukum dengan lebih cepat. Hal ini yang mendasari perlu dilakukan pengembangan E-Law Consult sebaga wadah perlindungan hukum bagi Guru-Guru di Jawa Tengah untuk menjawab kebutuhan mobilitas masyarakat akan hukum sehingga dengan E-Law Consult diharapkan masyarakat dapat mengetahui hukum dengan baik.

Dari latar belakang di atas peneliti menganggap perlu dilakukan pengembangan E-Law Consult sebagai wadah perlindungan hukum bagi guru-guru di Jawa Tengah. Berdasarkan hal tersebut, permasalahan yang dibahas dalam tulisan ini adalah: (1) Apa kelemahan perlindungan hukum bagi guru sebagai pendidik profesional di Jawa Tengah saat ini? (2) Bagaimana mengatasi kelemahan perlindungan hukum bagi guru sebagai pendidik profesional di Jawa Tengah saat ini dengan menggunakan aplikasi E-Law Consult?

\section{B. Metode Penelitian}

Metode penelitian yang digunakan dalam penelitian ini adalah yuridis-empiris dengan menggunakan paradigma positivisme yaitu paradigma yang memandang bahwa ilmu hukum hanya berkutat pada perundang-undangan belaka. Hukum adalah sesuatu yang harus diterapkan, dan kemungkinan besar tidak mempersoalkan nilai keadilan dan kegunaannya bagi masyarakat. Kajian dan penegakan hukum hanya berkisar pada apa yang benar dan apa yang tidak benar, apa yang salah dan apa yang tidak salah dan bentuk lain yang lebih bersifat preskriptif. Tujuan akhirnya adalah untuk melihat apa saja kelemahan dari perlindungan hukum guru saat ini sebagai tenaga profesional di
Jawa Tengah dan bagaimana cara mengatasinya untuk sesuai dengan hukum dan juga prinsip edukasi yang baik (Cronbach, 1977).

Pengembangan Aplikasi E-Law Consult mengacu prosedur pengembangan perangkat pembelajaran menggunakan model yang dikembangkan Borg dan Gall (1983) yang memfokuskan pada bidang product development. Pendekatan penelitian ini bersifat yuridis sosiologis, artinya hasil penelitian ini berusaha memberikan gambaran yang komprehensif, penelitian yang mendalam dan nyata yang dilakukan terhadap situasi nyata masyarakat atau lingkungan masyarakat dengan maksud dan tujuan untuk menemukan fakta (factdiscovery), yang kemudian menuju identifikasi masalah dan pada akhirnya mengarah pada pemecahan masalah (Cook, 2006).

\section{Hasil dan Pembahasan}

\section{Kelemahan Perlindungan Hukum bagi Guru sebagai Pendidik Profesional di Jawa Tengah Saat Ini}

Untuk memahami kelemahan perlindungan hukum guru sebagai tenaga profesional di Jawa Tengah saat ini, hal pertama yang harus dilakukan adalah menganalisis kerangka kerja perlindungan hukum guru secara profesional sebagaimana tertuang dalam Undang-Undang Nomor 14 Tahun 2005 tentang Guru dan Dosen yaitu pada Bab I Pasal 1 (1) yang mengatur bahwa "Guru adalah pendidik profesional yang tugas pokoknya mendidik, menilai". Pada ayat (2) dijelaskan bahwa "Profesional adalah pekerjaan atau kegiatan yang dilakukan oleh seseorang dan menjadi sumber penghasilan penghidupan yang memerlukan keahlian, keterampilan, atau keterampilan yang memenuhi standar kualitas atau norma tertentu dan memerlukan pendidikan profesional". Dari Undang-undang ini yang kemudian diturunkan dalam bentuk Peraturan Pemerintah tepatnya dalam Peraturan Pemerintah Nomor 74 Tahun 2008 tentang 
Guru yang mengatur tentang pelaksanaan Undang-Undang Nomor 14 Tahun 2005 tentang Guru dan Dosen, khususnya Pasal 40 ayat 1 disebutkan bahwa "Guru berhak mendapat perlindungan dalam menjalankan tugasnya berupa keselamatan dan keselamatan kerja dari Pemerintah Pusat, Daerah, satuan pendidikan, organisasi profesi guru, dan/atau masyarakat sesuai dengan kewenangannya".

Selanjutnya disebutkan bahwa "Guru berhak atas perlindungan hukum dari tindak kekerasan, ancaman, perlakuan diskriminatif atau perlakuan tidak adil terhadap peserta didik, orang tua peserta didik, masyarakat, birokrasi atau pihak lain".

Terhadap hal tersebut, ada beberapa poin penting yang harus diperhatikan. Pertama, guru adalah suatu profesi yang dalam melaksanakan pekerjaannya guru berhak mendapat perlindungan. Artinya selama seseorang melaksanakan pekerjaannya dan sesuai dengan standar pelaksanaan pekerjaan, maka profesi guru harus dilindungi secara hukum. Tidak ada satu lembaga atau entitas individu yang dapat dan dapat campur tangan dalam kegiatan profesionalnya. Sebagai suatu profesi, guru memiliki standar mutu dalam pelaksanaan tugasnya atau disebut kompetensi. Undang-Undang Nomor 14 Tahun 2005 tentang Guru dan Dosen pasal 10 ayat (1) menyatakan bahwa: "Kompetensi guru meliputi kompetensi pedagogik, kepribadian, sosial, dan profesional.

Ketentuan di atas kemudian diperjelas dalam Peraturan Pemerintah Nomor 32 Tahun 2013 jo Peraturan Pemerintah Nomor 19 Tahun 2005 tentang Standar Nasional Pendidikan. Undang-undang tersebut kemudian secara teknis dituangkan ke dalam Peraturan Menteri Pendidikan (Permendiknas) No. 16 tahun 2007 tentang Standar Kualifikasi dan Kompetensi Guru. Jadi dalam kenyataannya guru sebagai suatu profesi telah dilindungi sesuai dengan hukum yang berlaku sebagaimana tersebut di atas meskipun penegakannya masih belum tepat karena masih menomorduakan eksistensi Guru sebagai tenaga pengajar dan lebih mengutamakan keberadaan anak itu sendiri (S. dan R. K. S. Budoyo, 2019).

Kedua, guru adalah manusia - tidak hanya mengacu pada profesinya - artinya dalam menjalankan aktivitasnya selalu melibatkan jiwa (psikis, mental, spiritual) dan raga (raga dan seluruh indera). Mengingat bahwa pekerjaan guru tidaklah sederhana dan bahwa objek karyanya juga manusia yang memiliki kondisi emosi yang beragam, tidak menutup kemungkinan terjadinya konflik antara subjek dan objek (Sandefur, 2016).

M. Saekan Muchith (2007) dalam buku Contextual Learning memberikan contoh lain yang dapat mengkaji kondisi yang terjadi pada sudut pandang yang berbeda untuk suatu pandangan yang obyektif seperti kejadian di Magelang, dimana siswa SD ditampar gurunya hanya karena siswa menginterupsi pembicaraan gurunya, yaitu memberikan pengumuman pertunjukan sulap. Di Tanjung pinang ada oknum guru olah raga yang menendang siswanya saat belajar karena alasan pendidikan. Di Kabupaten Takalar, Sulawesi Selatan, para guru melakukan mogok dengan alasan salah satu guru agama di sekolah tersebut dipenjara selama enam bulan karena memukul siswanya. Aksi mogok tersebut dimaksudkan sebagai aksi protes untuk mencegah pembebasan guru agama yang dipenjara.

Guru di satu sisi perlindungannya sebagai tenaga profesional masih lemah bukan hanya karena perangkat hukum yang ada tetapi juga dari guru itu sendiri, seperti terlihat pada contoh di atas. Oleh karena itu dibutuhkan saling pengertian, saling pengertian, dan tentunya pengendalian emosi terutama dari guru sebagai manusia yang lebih matang daripada peserta didik sebagai tujuan untuk memanusiakan pendidikan manusia dengan cara yang manusiawi sehingga terwujud tatanan saling menghargai dan menghargai (Purwanto, 1995).

Dalam standar kompetensi kepribadian, guru dituntut memiliki pribadi yang matang 
dalam bertindak dan matang dalam berpikir. Begitu pula dalam standar kompetensi pedagogik guru dituntut untuk memahami kondisi setiap siswanya.

Dari uraian di atas jelaslah bila dalam melihat kasus penganiayaan guru oleh orang tua peserta didik, harus terlebih dahulu memperhatikan kronologi kejadian secara keseluruhan agar mendapatkan hasil yang objektif. Apa yang dilakukan guru ketika menegur peserta didik dengan cara menampar, jika benar maka perbuatan yang dilakukan sudah di luar kaidah profesinya. Undang-Undang Nomor 14 Tahun 2005 tentang Guru dan Dosen tidak membenarkan adanya kekerasan, baik secara verbal maupun non verbal dalam proses pendidikan. Jika terjadi kekerasan di satuan pendidikan, salah satu ancamannya adalah mencabut izin operasional sekolah (Astawa, 2016).

Gesekan ini, seharusnya tidak terjadi sejak awal jika sosialisasi hak-hak yang dimiliki guru sebagai pendidik profesional diketahui oleh guru sendiri, orang tua dan masyarakat sebagai negara kita menganut asas fiksi hukum (Engler, 2016). Fiksi hukum adalah prinsip yang mengasumsikan bahwa setiap orang mengetahui hukum (Presumptio Iures De Iure). Setiap orang dianggap tahu hukum, termasuk petani yang tidak tamat SD, atau warga yang tinggal di pedalaman. Dalam bahasa Latin dikenal juga sebagai Ignorantia Jurist Non Excusat Adagium, atau ketidaktahuan hukum tidak dapat dimaafkan (Muchith, 2016). Seseorang tidak dapat menghindari keterikatan hukum dengan menyatakan bahwa dia belum atau tidak mengetahui hukum dan peraturan tertentu (Steinberg, 2011).

Fiksi hukum sebenarnya memiliki konsekuensi bagi Pemerintah. Setiap aparatur pemerintah wajib menyampaikan peraturan perundang-undangan tertentu kepada masyarakat. Jika orang yang tidak melek hukum kemudian diseret ke pengadilan meski sebenarnya tidak tahu hukum, penyelenggara negara juga harus merasa bersalah, dan untuk menghindari hal tersebut, pemerintah berkewajiban untuk menyebarluaskan setiap produk peraturan perundang-undangan kepada masyarakat sebagaimana diatur oleh Presiden dalam Peraturan Presiden Nomor 1 Tahun 2007 tentang Pengesahan, Pengesahan, dan Penyebarluasan Peraturan Perundangundangan, mengenai seberapa besar Indonesia, mensosialisasikan Perda tersebut bukanlah tugas yang mudah karena menurut Atang (Usman, 2014), masih banyak masalah karena pemahaman hukum Indonesia masih kurang karena hal tersebut disebabkan oleh beberapa masalah berikut: (a) Tidak mengetahui tentang persyaratan hukum dan kurangnya pemahaman hukum; (b) cenderung kurang menghargai dalam mempercayai proses penegakan hukum yang sedang berlangsung; (c) integritas dan faktor moral rendah; (d) faktor sarana dan prasarana masih belum memadai.

\section{Mengatasi Kelemahan Perlindungan Hukum bagi Guru sebagai Pendidik Profesional di Jawa Tengah Saat Ini dengan Menggunakan Aplikasi E- Law Consult}

Berdasarkan permasalahan di atas, maka kebutuhan sosialisasi regulasi dapat dilakukan dengan bantuan masyarakat dan di antara banyak cara sosialisasi dengan menggunakan teknologi terkini dapat menjadi salah satu media penyelesaiannya, yaitu konsultasi hukum elektronik sebagai salah satu sarana untuk membantu guru dalam menghadapi masalah hukum terkait profesinya sebagai guru.

Penerapan bantuan hukum pada dasarnya bukanlah sesuatu yang baru. Kebutuhan masyarakat karena mobilitasnya yang tinggi sehingga dalam menghadapi permasalahan hukum sulit meluangkan waktu untuk bertemu dengan advokat sebagai dasar pembuatan aplikasi berbasis android bekerjasama dengan Renggali Visi Berjaya (RVB) dan Asosiasi Pengacara Pengadaan Indonesia (APPI) disebut Halo Lawyer (Tribunnews, 2017). Aplikasi ini pada dasarnya adalah aplikasi chat atau messaging, yaitu aplikasi interaksi tekstual 
dengan pengacara atau advokat yang berkaitan dengan masalah hukum. Berbeda dengan Halo Lawyer, aplikasi Electronic Law Consult mengutamakan teknologi dalam arti tersendiri yakni bersifat eksklusif untuk guru sebagai pengajar profesional dan hanya ada di Jawa Tengah.

Aplikasi ini ditujukan untuk digunakan dalam sistem berbasis Android karena masyarakat saat ini tidak dapat dipisahkan dari teknologi Android. Perangkat ini berbeda dengan komputer atau laptop, jauh lebih portabel karena perangkat telekomunikasi berbasis Android atau yang lebih dikenal dengan smartphone ini lebih portabel, dengan fungsi yang sama bahkan lebih dari sekedar laptop atau komputer (seperti layanan pengiriman pesan singkat, menelepon) dan satu hal yang paling unik dari smartphone ini adalah sistem aplikasi atau App, yaitu perangkat lunak yang diinstal pada smartphone. Berbeda dengan perangkat lunak yang diinstal pada perangkat komputer, Aplikasi tersebut diinstal pada Smartphone yang dalam hal spesifikasi di bawah komputer perangkat umumnya membuat aplikasi sistem lebih sederhana. Hal ini ditambah lagi dengan banyaknya pengguna smartphone karena harganya yang lebih murah dan lebih portabel dibandingkan laptop atau komputer seperti terlihat dari data yang dirilis oleh Asosiasi Penyelenggara Jaringan Internet Indonesia (APJII) dimana jumlah pengguna smartphone di Indonesia pada bulan Oktober tahun 2016 saja mencapai 132,7 juta jiwa, dari total penduduk Indonesia yang berjumlah 256,2 juta jiwa sehingga dapat disimpulkan lebih dari separuh atau tepatnya 51,8 persen penduduk Indonesia merupakan pengguna smartphone (Kompas, 2017).

Melihat potensi di atas, bukan tidak mungkin alat ini dapat digunakan sebagai media untuk memberikan informasi kepada masyarakat tentang hukum. Media yang dimaksud adalah Aplikasi Konsultasi Hukum Elektronik E-Law Consult yang merupakan aplikasi konsultasi hukum berbasis android yang dikembangkan untuk menjawab kebutuhan mobilitas masyarakat dalam bidang hukum sehingga dengan adanya aplikasi ini diharapkan masyarakat dapat mengenal hukum dengan baik.

Aplikasi E-Law Consult adalah sebuah aplikasi bantuan hukum yang berbeda dengan aplikasi sejenis lainnya, aplikasi ELaw Consult bukan merupakan system messaging atau chat dengan pengacara atau advokat melainkan sebuah sistem yang mengindeks glosarium kata-kata kemudian melalui aplikasi ini, pengguna mengetikkan permasalahan hukumnya pada kolom yang disediakan untuk kemudian kata-kata tersebut dicocokkan dengan glosarium yang ada yang sudah ditautkan dengan pasal-pasal dan aturan hukum yang ada dan langsung memunculkan hasilnya (permasalahan hukum yang dihadapi) saat itu juga. Hal ini merupakan sebuah terobosan besar di bidang hukum dan juga teknologi dimana teknologi dapat dimanfaatkan sebaik mungkin demi mencapai masyarakat yang sadar hukum.

Pengembangan Aplikasi E-Law Consult ini sendiri berpegang pada Teori Skema Pengembangan Aplikasi dari Borg dan Call (1983) yang dikenal dengan 10 langkah kerja model pengembangan sebagaimana dapat dilihat pada gambar di atas ialah sebagai berikut:

a. Research and Information Collecting Merupakan tahap dimana peneliti melakukan studi pendahuluan untuk mengkaji, menyelidiki, dan mengumpulkan informasi. Langkah ini dilakukan oleh peneliti untuk menganalisis kebutuhan dan mengindentifikasi masalah yang ada, sehingga dibutuhkan pengembangan media pembelajaran baru.

\section{b. Planning}

Perencanaan yang disusun merupakan rencana pengembangan produk. Aspek penting dalam perencanaan meliputi produk tentang tujuan dari produk, mengapa dikembangkan, dimana produk dikembangkan, siapa sasaran dari produk yang dikembangkan dan bagaimana proses pengembangannya. 
c. Develop Preliminary Form of Product Peneliti mulai mengembangkan bentuk produk awal (draft) yang bersifat sementara (hipotesis) yang merupakan bentuk awal dari pengembangan. Pada tahap ini dilakukan validasi produk oleh pakar yang telah ahli di bidangnya. Hasil dari validasi kemudian dikaji untuk memperbaiki rancangan model.

\section{d. Preliminary Field Testing}

Peneliti melakukan uji coba terbatas mengenai produk awal di lapangan yang melibatkan 10-15 subyek penelitian. Selama uji coba peneliti mengobservasi bagaimana subyek (guru) menggunakan produk pengembangan. Setelah melakukan uji coba melakukan wawancara dan dapat menyebarkan angket kepada subyek penelitian. Tujuan dari angket dan wawancara untuk penyempurnaan produk yang dikembangkan.

\section{e. Main Product Revision}

Peneliti melakukan revisi pertama, yaitu perbaikan dan penyempurnaan terhadap produk berdasarkan hasil dari uji coba pertama yang dilakukan.

\section{f. Main Field Testing}

Dilakukan uji coba produk dengan skala yang lebih luas. Uji coba ini melibatkan subjek penelitian antara 30 sampai dengan 100 orang. Sampel yang dipilih pada uji coba bersifat representatif, sehingga produk dapat berlaku secara umum.

\section{g. Operational Product Revision}

Setelah dilakukan uji coba lapangan, produk direvisi sesuai dengan hasil uji coba. Peneliti memperbaiki dan menyempurnakan produk berdasarkan revisi uji coba lapangan.

\section{h. Operational Field Testing}

Peneliti melakukan uji pelaksanaan, yakni uji dengan skala yang lebih besar dan luas. Uji pelaksanaan lapangan melibatkan 40-200 subjek penelitian. Data yang dikumpulkan melalui wawancara, observasi, dan angket. Jika peneliti tidak mau sampai mengetahui dampak produk peneliti, maka tidak perlu ada kelompok kontrol.

\section{i. Final Product Revision}

Peneliti melakukan revisi terhadap produk sesuai dengan hasil uji pelaksanaan lapangan yang telah dilakukan. Tahap ini merupakan revisi terakhir untuk memperbaiki dan menyempurnakan produk sebelum dipublikasikan.

\section{j. Dissemination and Implementation}

Tahap terakhir yang dilakukan peneliti dengan menyebarluaskan produk untuk disosialisasikan kepada seluruh subjek, sehingga subjek akan mengimplementasikan produk tersebut.

Untuk saat ini Aplikasi E-Law Consult menyediakan 2 Versi. Versi pertama ialah versi website dengan alamat: https:/elawconsult.com/. Versi ini menyediakan informasi Umum tentang aplikasi E-Law Consult sekaligus sebagai media untuk melakukan konsultasi hukum secara umum yang dapat dilihat oleh orang lain. Tampilan dari versi ini dapat dilihat pada Gambar 1.

Sedangkan versi kedua ialah versi yang tersedia pada sistem Android. Sistem pada versi yang kedua ini tersedia bagi pengguna yang memerlukan konsultasi hukum secara privat atau rahasia. Tampilan dari aplikasi ini dapat dilihat pada Gambar 2. 


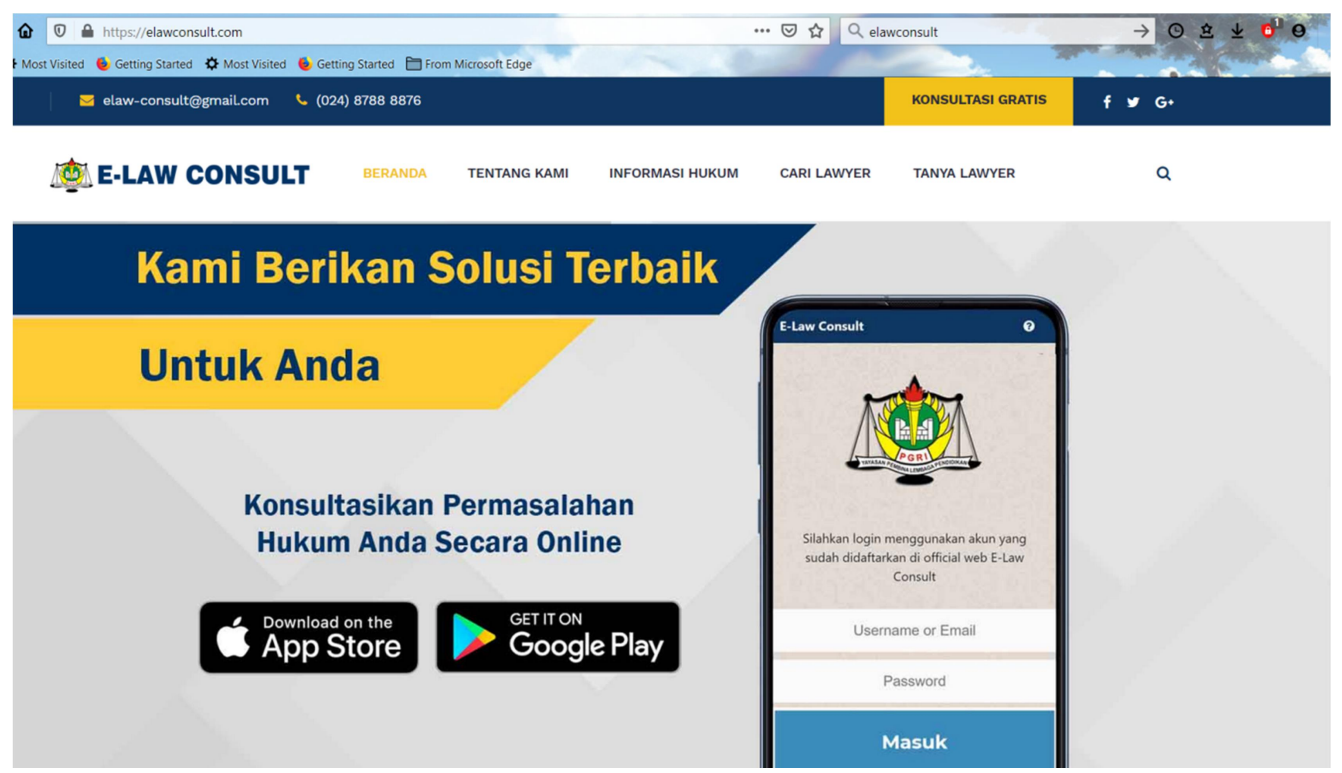

Gambar 1. Tampilan Awal Website E-Law Consult

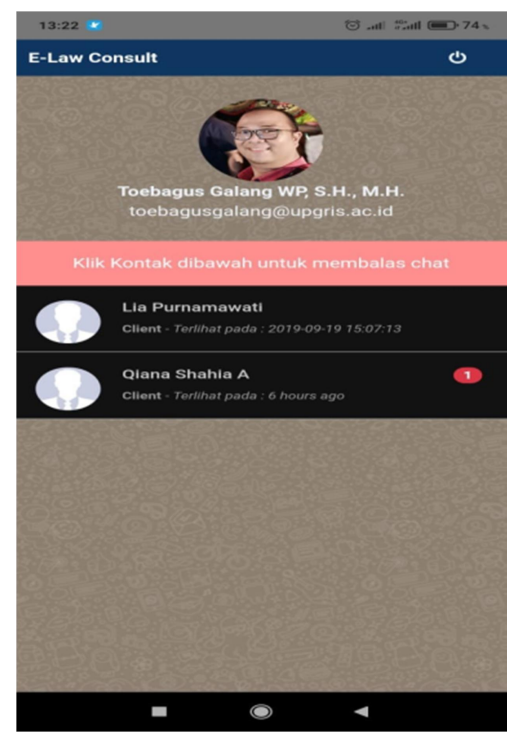

\section{Gambar 2. Tampilan Awal App Android E-Law Consult}

Aplikasi E-Law Consult sampai Artikel ini dibuat telah sampai pada tahap Preliminary Field Testing yang melibatkan sampel subyek penelitian. Selama uji coba peneliti mengobservasi bagaimana subyek (guru) Untuk mengetahui efektifitas E-Law Consult. Berdasarkan hasil uji produk awal pada sampel guru anggota PGRI di Jawa Tengah diperoleh data bahwa guru di Jawa Tengah belum memahami tentang perlindungan hukum yang ada. PGRI Jawa Tengah sudah memiliki firma hukum yang membantu masalah guru, namun kurang dari 50 persen guru yang mengetahui adanya firma konsultan hukum di Jawa Tengah yang khusus melindungi guru, oleh karena itu diperlukan terobosan agar guru terlindungi, salah satu mereka membuat perlindungan guru melalui web yang dapat diakses dimanapun dan kapanpun oleh semua guru di Jawa Tengah (Maryanto, 2020).

Hasil dari Preliminary Field testing tersebut menurut hemat penulis dapat menjadi dasar untuk penerapan Main Field Testing secara lebih luas di wilayah Jawa Tengah sehingga hasil feedback yang didapatkan lebih akurat terhadap 
pengembangan produk aplikasi sehingga ke depannya aplikasi ini dapat digunakan secara efektif di dalam membantu guru agar mendapatkan perlindungan hukum yang layak sebagaimana tenaga profesional lainnya.

\section{Simpulan dan Saran}

Berdasarkan hasil pembahasan di atas dapat disimpulkan bahwa hak guru sebagai Pendidik Profesional di mata hukum adalah perlindungan hukum sebagaimana diamanatkan oleh UU No. 14 Tahun 2005 Guru dan Dosen belum mampu melindungi guru saat guru dihadapkan pada UU No. 23 Tahun 2002 tentang Perlindungan Anak sebagaimana telah diubah dengan UU No. 35 Tahun 2014. Guru yang melakukan tindakan fisik "tertentu" dalam tugasnya sebagai pendidik pada siswanya dapat dimintai keterangan secara hukum jika dinilai melanggar ketentuan UndangUndang Perlindungan Anak. Tidak sedikit guru yang harus berhadapan dengan polisi, diadili di pengadilan atau bahkan dipenjara sehingga untuk mengatasi hal tersebut, selain perlu adanya hak imunitas (immunity right) yang diatur dalam Undang-Undang, diperlukan media untuk menyosialisasikan ketentuan tentang guru sebagai profesi.

Untuk mengatasi kurangnya pemahaman guru, siswa dan orang tua murid tentang hukum yang berlaku dalam hubungannya dengan tugas profesional guru perlu adanya sosialisasi tentang hak-hak yang dimiliki oleh guru, orang tua dan masyarakat serta di antara banyak cara sosialisasi dengan menggunakan teknologi terkini dapat menjadi salah satu media penyelesaiannya dimana dalam hal ini ialah Aplikasi E-Law Consult sebagai sarana untuk membantu guru dalam menghadapi permasalahan hukum terkait profesinya sebagai guru di Jawa Tengah. Aplikasi ini dikembangkan berdasarkan metode pengembangan Aplikasi Borg dan Call dimana dalam tahap Preliminary Field Testing mendapat cukup banyak respon positif dari sampel dan siap diujicobakan ke dalam taraf yang lebih luas.

\section{DAFTAR PUSTAKA}

Astawa, I. G. P. (2016). Law Enforcement Responsibilities in the Law Enforcement System to respond to the public. Justice seekers (An Academic Review). Jakarta.

Budoyo, S. (2018). Peranan Perguruan Tinggi Dalam Mengatasi Problematika Hukum Di Indonesia. Jurnal MetaYuridis, $1(1)$. http://doi.org/10.26877/m-y.v1i1.2864

Budoyo, S. dan R. K. S. (2019). Eksistensi Restorative Justice Sebagai Tujuan Pelaksanaan Diversi Pada Sistem Peradilan Anak Di Indonesia. Jurnal Meta-Yuridis, 2(2). http://doi.org/10.26877/m-y.v2i2.4689

Cook, S. and. (2006). Introduction: Democracy and Education. Canadian Journal of Education, 29(2), 347-358.

Cronbach, L. J. (1977). Educational psychology. Chicago: John Wiley \& Sons.

Engler, R. (2016). And Justice For AllIncluding the Unrepresented Poor: Revisiting the Roles of the Judges, Mediators, and Clerks. Fordham Law Review, 67(5), 1987-2070.

Kompas, T. (2017). Pengguna Internet di Indonesia capai 132 Juta. Retrieved January $17, \quad 2020, \quad$ from http://tekno.kompas.com/read/2016/10/ 24/15064727/2016.pengguna.internet.di .indonesia.capai.132.juta.

Maryanto, E. a. (2020). Design of e-law Consult to Protect Teacher in Central java Indonesia. Test Engineering and Management, 82, 1455-1463.

Muchith, S. (2016). Radikalisme dalam Dunia Pendidikan. $A D D I N, 10(1)$.

Purwanto, P. dan M. N. (1995). Psikologi Pendidikan. Bandung: Remaja Rosdakarya.

Sandefur, R. L. (2016). What We Know and 
Need to Know About the Legal Needs of the Public. South Carolina Law Review, 67(2), 443-460.

Steinberg, J. K. (2011). In Pursuit of Justice? Case Outcomes and the Delivery of Unbundled Legal Services. Georgetown Journal on Poverty Law \& Policy, 18(3 Symposium Issue 2011), 453-505.

Tribunnews. (2017). Halo Lawyer Aplikasi Baru Untuk Konsultasi Hukum Hadir
Di Smartphone, diambil dari. Retrieved January 20, 2020, from http: //www.tribunnews.com/techno/2017/01/ 31/halo-lawyer-aplikasi-baru-untukkonsultasi-hukum-hadir-di-smartphone

Usman, A. H. (2014). Kesadaran Hukum Masyarakat Dan Pemerintah Sebagai Faktor Tegaknya Negara Hukum Di Indonesia. Jurnal Wawasan Hukum, $30(1)$. 